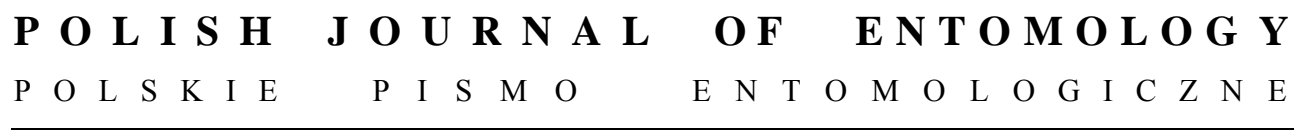

VOL. 81: 207-210

Gdańsk

30 September 2012

DOI: $10.2478 / \mathrm{v} 10200-012-0008-9$

\title{
Description of a female of Forcipomyia (Pedilohelea) eremita (Diptera: Ceratopogonidae) from Yemen
}

\author{
ALICJA ALWIN, RYSZARD SZADZIEWSKI \\ Department of Invertebrate Zoology and Parasitology, University of Gdańsk, \\ Wita Stwosza 59, 80-308 Gdańsk, Poland, \\ e-mails: alicjaalwin@wp.pl; biorys@ug.edu.pl
}

ABSTRACT. A female of Forcipomyia eremita SZADZIEWSKI, GWIZDALSKA-KENTZER \& GILKA, 2011 of the subgenus Pedilohelea DE MEILlON \& WIRTH, 1980 is described for the first time.

KEY WORDS: Diptera, Ceratopogonidae, Forcipomyia, Yemen.

\section{INTRODUCTION}

In the subgenus Pedilohelea 18 species are known, all recorded in the warm climate of the Neotropical, Afrotropical and Australasian regions (DEBENHAM 1987, BORKENT 2012). Species of this subgenus probably take part in the pollination of cocoa flowers and other crop plants (DE MEILLON \& WIRTH 1980). Only Forcipomyia eremita (SZADZIEWSKI et al. 2011), described from males collected in the United Arab Emirates, has been reported from the southern region of the Middle East. Among biting midges collected from Yemen, we identified an unknown female of that species. The description follows.

\section{Acknowledgements}

The authors thank Dr Antonius van Harten and Dr Wojciech Giłka for providing the material.

\section{MATERIAL AND METHODS}

The specimens of F. eremita (3 females, 1 male) were collected in Yemen by Dr Antonius van Harten (12 km NW of Manakhah, 24.06-04.08.2003, Malaise trap). 
They were preserved in 70\% alcohol, dissected and mounted on slides in a mixture of phenol and Canada balsam, as described by SZADZIEWSKI (1985). The material is housed in the collection of the Department of Invertebrate Zoology and Parasitology, University of Gdańsk.

Specimens examined: 3 females, 1 male, Yemen, $12 \mathrm{~km} \mathrm{NW}$ of Manakhah, 24.0604.08.2003, Malaise trap, leg. A. van Harten.

\section{DESCRIPTION}

\section{Forcipomyia (Pedilohelea) eremita}

Forcipomyia (Pedilohelea) eremita SZADZIEWSKI, GwIZDALSKA-KENTZER \& GIŁKA, 2011: 638 ( $\hat{0}$, United Arab Emirates).

\section{Female}

Similar to male with the usual sexual differences. Head yellowish. Eyes bare. Flagellum length $0.64-0.69 \mathrm{~mm}$, AR 0.77-0.86. Proximal flagellomeres 2-12 cylindrical, gradually increasing in length (Fig. 2). Fourth and fifth palpal segments fused. Third palpal segment slightly swollen in basal half, sensory pit shallow, with few sensilla capitata, length 0.068 $0.072 \mathrm{~mm}$. Palpal ratio 2.6-3.0. Thorax brownish. Wings uniformly yellow, length 1.11$1.25 \mathrm{~mm}, \mathrm{CR} 0.32-0.37$. Small first radial cell present. Legs yellow. Tarsal ratio of fore leg TR (I) 1.45 , TR (II) $0.78-0.80$, TR (III) 0.83 . Two unequal, large, ovoid seminal capsules present, neither one with a neck; the larger one $0.182-0.197 \mathrm{~mm} \times 0.098-0.136 \mathrm{~mm}$, the smaller one 0.106-0.139 $\mathrm{mm} \times 0.076-0.091 \mathrm{~mm}$.

\section{DISCUSSION}

In contrast to the known females of the subgenus Pedilohelea, the female of Forcipomyia eremita is characteristic in having two large and unequal seminal capsules. The seminal capsules of other known females in this subgenus are equal and about 2-3 times smaller than those of Forcipomyia eremita. The fourth and fifth palpal segments are completely fused, as in most species of this subgenus.

The species was known from the United Arab Emirates. From Yemen is reported for the first time.

\section{REFERENCES}

BORKENT A. 2012. World species of biting midges (Diptera: Ceratopogonidae). http://www.inhs.uiuc.edu/research/FLYTREE/CeratopogonidaeCatalog.pdf. 


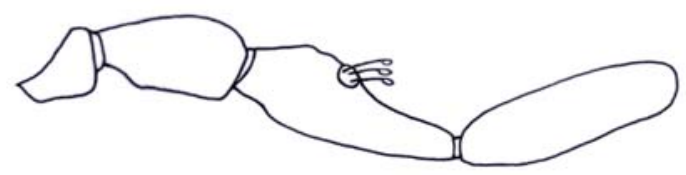

$0.1 \mathrm{~mm}$

1
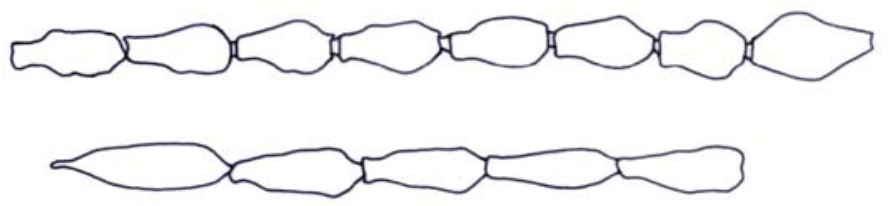

2

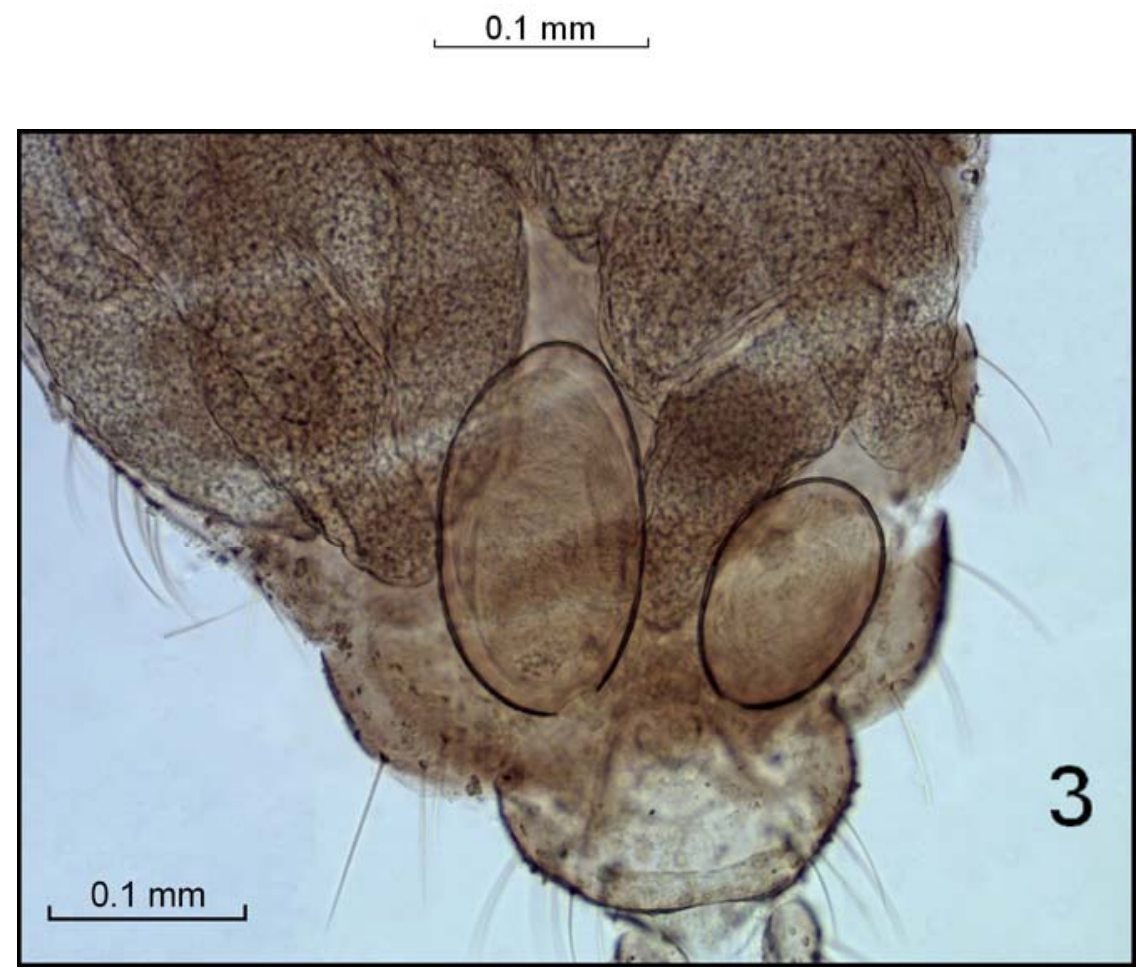

Figs 1-3. Female of Forcipomyia eremita SZADZIEWSKI, GwiZDALSKA-KentZER \& GiŁKA, 2011. 1 - palpus, 2 - flagellum, 3 - seminal capsules. 
De Meillon B.,WiRTh W.W. 1980. A new subgenus of Forcipomyia, with descriptions of eight new species (Diptera: Ceratopogonidae). Proceedings of the Entomological Society of Washington 82(1): 9-24.

SZADZIEWSKI R. 1985. Szybka metoda sporządzania totalnych preparatów mikroskopowych z drobnych muchówek. Wiadomości Entomologiczne 6(1-2): 95-100.

SzADZiewski R., GwizdALSKA-KenTZER M., GiŁKA W. 2011. Order Diptera, family Ceratopogonidae. [In:] H.H. Sheikh TAHNOON BIN Zayed Al NAHYAN (patron), van HARTEN A. (ed.). Arthropod fauna of the United Arab Emirates. Volume 4. Dar Al Ummah Printing, Publishing, Distribution \& Advertising, Abu Dhabi, UAE, pp.: 636-653.

Received: June 20, 2012

Accepted: August 8, 2012 